\title{
Kalmár Zoltán
}

Pannon Egyetem MFTK, Filozófia, Történettudomány és Antropológia Intézet

\section{Hogyan vált Izrael tengeri hatalommá?}

Korunkban a tengeri hatalom domináns eszközei a tengeralattjárók. A nukleáris töltetek célba juttatására is alkalmas cirkálórakétákkal felszerelt tengeralattjárók bármikor képesek végsố csapást mérni ellenséges területre. Az izraeli haditengerészet tengeralattjáró-flottája az egyik legnagyobb és legjelentósebb a Közel-Keleten. A tanulmány Izrael tengeralattjáró-flottájának fejlódését elemzi az 1950-es évek végétól napjainkig, és arra a kérdésre is választ keres, hogy milyen szerepet tölt be a tengeralattjáró-flotta az izraeli biztonsági stratégiákban.

\section{A kezdetek}

A z 1948-ban háborús viszonyok közepette létrejött Izrael fennállása első évtizedének végétől, 1957-től kezdte el önálló tengeralattjáró-flottájának kiépítését, s ezzel a zsidó állam belépett a tengeralattjáró haditengerészetek közösségébe (Mommsen, 2011, 84. o.). Erre a biztonsági fejlesztésre elsősorban az késztette, hogy legfőbb közel-keleti ellenfele, Egyiptom ${ }^{1}$ haditengerészetének számszerü adatai és technikai paraméterei többszörös fölényt mutattak az izraelihez képest. Az izraeli politikai vezetés 1957-ben két tengeralattjáró beszerzésével és hadrendbe állításával bízta meg Joszále Drórt, akit az izraeliek az 1950-es években Franciaországban a tengeralattjáró-elleni hadviselés szakértőjének képeztettek ki. Drór megfelelő tengeralattjáró-szállító partnert látott Franciaországban, Nagy-Britanniában, Svédországban, Norvégiában, Dániában, Hollandiában és Németországban, végül a marginális tengerek sekély vizeiben praktikus, kisebb brit tengeralattjárókat tartotta Izrael számára a legalkalmasabbaknak (Mommsen, 2011, 84-85. o.). Az izraeli haditengerészet tengeralattjáró fegyverneme két, Nagy-Britanniától vásárolt, $\mathrm{S}$ osztályú, dízel-elektromos meghajtású tengeralattjáróból alakult meg. A britek által felújított, szonárral és radarral felszerelt tengeralattjárók a Tannín és Ráháb nevet kapták. Mivel a két tengeralattjáró 1945-ben készült, ${ }^{2}$ második világháború előtti tervek alapján, ezért az izraeli kormány már 1959-es hadrendbe állásuk után fél évtizeddel korszerübbé átépített tengeralattjárók megrendeléséről döntött. Nagy-Britannia 1964-ben vállalta, hogy a következő három tengeralattjárót - a Leviátánt, a Dakart és a Dolphint - egy évtized alatt felújítja, és átadja az Izraeli Védelmi Erőknek. A három tengeralattjáró felújítása egymás után történt, s amikor egy elkészült, azt az izraeliek rendelkezésére bocsátották (Illés, 2005a, 73. o.; Illés, 2005b, 66. o.).

Az 1967. június eleji hatnapos arab-izraeli háború idején az izraeli haditengerészet két tengeralattjárójából a Ráháb múködésképtelen állapotban volt, ezért csak - szonárral és vízibombavető-készülékkel rendelkező - járőrhajóként tudott szolgálni. A másik tengeralattjáró, a Tannín hajtotta végre az első izraeli offenzív haditengerészeti müveletet a víz alatt, felemás eredménnyel: „Az egyetlen, lemerülni képes tengeralattjáró, a Tannín, a Sajetet 13 hat kommandósát bocsátotta útjára, azzal a céllal, hogy az alexandriai kikötő 
hajóit robbanótölteteikkel pusztítsák el. [...] Az izraeliek szerint kommandósaiknak bár később nem erősítették meg - két Osa rakétanaszádot és két tengeralattjárót sikerült megrongálni vagy elpusztítani, ezzel szemben az egyiptomiak csak egy kotróhajó, egy ellátóhajó és egy úszódokk csekély rongálódásáról számoltak be. A tengeralattjáró még másnap reggel is a találkaponton járörözött. Végül nem sokkal napkelte után a Tannín kísérletet tett az egyiptomi Tarik fregatt megtorpedózására, azonban négy torpedója nem talált, $\mathrm{s}$ az ezt követő vízibombázás során súlyosan megsérült. Emiatt képtelen volt fedélzetére venni a még mindig a kikötőben tartózkodó kommandósokat. A küldetés megbukott, a reggeli órákban mind a hat kommandóst elfogták a Kajt Bej Erőd közelében a keleti kikötőnél és egy csatornánál” (Illés, 2005a, 73-75. o.).

A délkelet-angliai Portsmouth hajógyárában elsőként felújított tengeralattjáró, a Leviátán 1967 májusában indult Izraelbe, s a hatnapos háború befejeződése másnapján érkezett meg Haifába. A Dakar felújításával 1967 novemberében, a Dolphinéval 1968 januárjában végeztek a britek, s az izraeli parancsnoknak és legénységnek átadott tengeralattjárók próbaútjaikat és gyakorló merüléseiket még Nagy-Britannia közelében végezték.

A Dakar (Kardhal) tengeralattjáró 1968. január 9-én, 69 tengerésszel a fedélzetén indult Izraelbe. A Jaakov Raanan parancsnoksága alá tartozó tengeralattjáró hat nap múlva Gibraltárnál úszott be a Földközi-tengerre. A Dakar utoljára január 24-én reggel jelentette aktuális pozícióját, ekkor Kréta és Ciprus között tartózkodott. Utolsó általános bejelentkezését január 25-én 0 óra 2 perckor regisztrálták. Az izraeli kereső egységek brit, görög, török és amerikai segítséggel másfél héten át kutattak a Dakar után, de nem bukkantak az eltünt tengeralattjáró nyomára. ${ }^{3}$

\section{Az új tengeralattjárók kora}

A Dakar katasztrófája jelentős mértékben hozzájárult ahhoz, hogy az izraeli tengeralattjáró-flotta fejlesztése vonatkozásában szemléletváltás következett be. Az izraeli politikai és katonai vezetés szakított a használt és bizonyos mértékig már elavult tengeralattjárók megvásárlásának gyakorlatával, ehelyett az új, a legmodernebb haditechnikával felszerelt tengeralattjárók beszerzését preferálta. Az új fejlesztési stratégia szerinti első megrendelésre 1972 áprilisában került sor, amikor Izrael a brit Vickers cégnek adott megbízást a német mérnökök által tervezett és német mérnökök közremüködésével megépítendő 206A típusú tengeralattjáró gyártására (Illés, 2005b, 67-68. o.).

A német fejlesztésü tengeralattjárók előtérbe kerülése szintén paradigmaváltást jelentett. Izrael és a Német Szövetségi Köztársaság között már 1957 óta zajlottak fegyverszállítási tárgyalások. A német Bundeswehrnek, amely a második világháború után 1955-től fegyverkezhetett, korszerü kézifegyverekre volt szüksége, s ezekre a legalkalmasabbaknak az Izrael által kínált, 1940-es évek végén tervezett és az Izraeli Védelmi Erők különleges egységeinél 1954-től rendszeresített Uzi géppisztolyok tűntek. Ezek mellett a németek izraeli aknavetőket is vásároltak. A német-izraeli fegyverüzlet azért is fontos volt, mert a németek ezzel - a második világháborúban a zsidókkal szemben elkövetett büneik némi ellentételezéseként - anyagilag támogatni tudták a zsidó államot. A Német Szövetségi Köztársaság nemcsak vásárolt izraeli hadiipari termékeket, hanem 1959-töl egyre nagyobb összegü, ingyenes katonai szállítmányok Izraelbe küldésével járult hozzá az Izraeli Védelmi Erők korszerüsítéséhez (Lavy, 1996.).

Izraelben 1982-től ismét felmerült a tengeralattjáró-flotta korszerüsítésének, a Vickers Hajógyárban 1973 és 1977 között, német tervek alapján gyártott három tengeralattjáró cseréjének igénye. Az izraeli vezetés 1986-ban konkrétan is megfogalmazta, hogy öt új, közepes méretü tengeralattjárót szeretne beszerezni. Több évig elhúzódtak a finanszírozás körüli egyeztetések. Izrael az Egyesült Államoktól várta a projekt finanszí- 
A német fejlesztésú tengeralattjárók elótérbe kerülése szintén paradigmaváltást jelentett. Izrael és a Német Szövetségi Köztársaság között már 1957 óta zajlottak fegyverszállitási tárgyalások. A német Bundeswehrnek, amely a második világháború után 1955-tól fegyverkezhetett, korszerú kézifegyverekre volt szüksége, s ezekre a legalkalma1940-es évek végén tervezett és az Izraeli Védelmi Erốk különleges egységeinél 1954-tól rendszeresitett Uzi géppisztolyok tüntek.

Ezek mellett a németek izraeli aknavetóket is vásároltak. A német-izraeli fegyverüzlet azért is fontos volt, mert a németek ezzel - a második világháborúban a zsidókkal szemben elkövetett búneik némi ellentételezéseként - anyagilag támogatni tudták a zsidó államot. A Német Szövetségi Köztársaság nemcsak vásárolt izraeli hadiipari termékeket, hanem 1959-tól egyre nagyobb összegú, ingyenes katonai szállitmányok Izraelbe küldésével járult hozzá az Izraeli Védelmi Erók korszerúsitéséhez (Lavy, 1996.). sabbaknak az Izrael által kinált,

rozását, a tárgyalások során a zsidó állam ötből kettőre csökkentette az általa igényelt tengeralattjárók számát. Washington 1989ben úgy döntött, hogy a két tengeralattjáró teljes költségének nagyobb részét finanszírozza, amennyiben Németország kifizeti a kisebb részt és az amerikai Litton Ingalls céget nevezik meg fövállalkozóként. Bár a két német állam egyesülése komoly anyagi terhet jelentett Németország számára, Helmut Kohl ${ }^{4}$ (CDU) szövetségi kancellár 1991. január 30-án vállalta, hogy a németek az 1,2 milliárd márkás Izraelnek történő katonai szállítások keretében 880 millió márkával hozzájárulnak a két tengeralattjáró megépítéséhez, tehát a kiváló minőségü fegyverrendszerek gyártásáról híressé vált Németországtól Izrael ismét jelentős pénzügyi támogatást kapott. Abban, hogy 1991 elején Németország az izraeli tengeralattjáró-kérések teljesítése mellett foglalt állást, ${ }^{5}$ az is közrejátszott, hogy az öbölháború idején ${ }^{6}$ Szaddám Huszein Irakjából olyan Scud-rakétákkal lőtték Izraelt, amelyek korszerüsítéséhez német cégek szállítottak alkatrészeket (Nassauer, 2011). A kieli központú német hajóépítő cég, a Howaldtswerke-Deutsche Werft 1992 elején elkezdte a két, dízel meghajtású tengeralattjáró kivitelezését (Steinmetz, 2002). A német politikai vezetés szerint Németország ezekkel a tengeralattjárókkal kizárólag az izraeli parti vizek őrzését kívánta erősíteni.

Az 1990-es évek első felében Izrael egy harmadik tengeralattjárót is meg akart rendelni Németországtól, az előző kettőhöz hasonló feltételekkel. Az éveken át húzódó német-izraeli-amerikai tárgyalások eredményeként 1995 februárjában megszületett a harmadik tengeralattjáróról is a megállapodás (Steinmetz, 2002). A három, egyenként 57 méter hosszú tengeralattjárót 1999 júliusa és 2000 októbere között adták át az izraeli haditengerészetnek. ${ }^{7}$ Németország végül mindhárom tengeralattjáró összköltségének több mint 80 százalékát finanszírozta (Nassauer, 2009), így ezek Németország adományainak is tekinthetők.

A legmodernebb fegyverrendszerekkel, nukleáris töltetek célba juttatására is alkalmas cirkálórakétákkal felszerelt új Dolphinek nem rendelkeztek ugyan nukleáris meghajtással, de a beépített üzemanyagcellás meghajtás révén nehezen bemérhetők és megsemmisíthetők. Képesek a vízfelszín alatt kétszáz méter mélységben tartózkodni, és 
egy tengeralattjárón elegendő egyszerre mindössze 30-40 tengerésznek szolgálatot teljesítenie. Jóllehet az izraeli hadseregben természetes az, hogy a nők számára is kötelező a katonai szolgálat, a tengeralattjárókon azonban kizárólag férfiak képezik a legénységet.

\section{Nukleáris csapásmérő tengeralattjárók}

A Németország által megépített három, radarok által szinte észlelhetetlen Dolphin osztályú tengeralattjárót torpedóvető csövekkel szerelték fel. Izrael ezeket tengeralattjárókat már stratégiai jelentőségüeknek tekintette. A hivatalosan nem atomhatalom, de ekkor valószínüleg legalább 100-200 nukleáris fegyverrel rendelkező ${ }^{8}$ zsidó állam az új tengeralattjárókra nukleáris robbanófejek hordozására képes robotrepülögépeket telepített. Izrael 2000 nyarán sikeres tengeri robotrepülőgép kísérletet hajtott végre - a teszthez hagyományos töltetet használva - a Srí Lanka-i partoktól 1000-1500 kilométerre. A zsidó állam ezáltal az Egyesült Államok és Oroszország mellett a harmadik olyan tengeri hatalommá vált, amely tengeralattjáróról képes nukleáris robbanófejeket hordozó robotrepülögépet indítani, és több mint 1500 kilométer távolságba célba juttatni (Uzi-Matthew, 2000; Nassauer, 2009).

Az ezredfordulón hadrendbe állított három Dolphin tengeralattjárót Izrael kevésnek találta védelme biztosítására, ezért a kézezres évek elején két újabb, legfejlettebb technológiájú tengeralattjárót kért a berlini kormánytól. A német politikai vezetés 2000 óta határozottan kiállt azon politikai alapelv mellett, miszerint a német állam konfliktusövezetbe nem szállít harci eszközöket, Izraellel kapcsolatban azonban 2005 novemberében kivételt tett: Gerhard Schröder ${ }^{9}$ (SPD) szövetségi kancellár szociáldemokrata-zöld kormánya újabb két Dolphin osztályú tengeralattjáró szállításáról tett ígéretet a zsidó államnak. A tengeralattjárók izraeli megvásárlásához a németek ekkor ismét jelentős anyagi támogatást helyeztek kilátásba, a vételár egyharmadának finanszírozásával. ${ }^{10} \mathrm{~A}$ zsidó állam negyedik és ötödik Dolphin osztályú, levegőfüggetlen meghajtású tengeralattjárója ${ }^{11}$ 2014 szeptemberében és 2016 januárjában csatlakozott az izraeli haditengerészeti flottához. „A levegőfüggetlen meghajtású tengeralattjárók felbecsülhetetlen előnyt biztosítanak Izraelnek - összegezte az új egységek stratégiai jelentőségét Otfried Nassauer. Ez megnöveli a hatótávolságot és föleg a lehetséges merülési időt olyan mértékben, hogy krízis idején lehetővé válik legalább egy tengeralattjárót bevetni az iráni partoknál úgy, hogy ezalatt egy másik úton van Izrael és a bevetési hely között" (Nassauer, 2011).

2009 öszén az izraeli kormány tárgyalásokat kezdett egy újabb tengeralattjáró beszerzéséről, s 2011 nyarán sikerült megrendelnie Németországtól a hatodik Dolphin osztályú, a korábbi kettőhöz hasonlóan levegőfüggetlen meghajtású tengeralattjáróját. ${ }^{12}$ Németország ezúttal is a teljes vételár egyharmadának finanszírozását vállalta, $\mathrm{s}$ a világ legmodernebb dízel-elektromos tengeralattjárói közé tartozó Dolphinek újabb egysége előreláthatólag 2017-ben állhat hadrendbe az izraeli haditengerészetnél.

$\mathrm{Az}$ izraeli haditengerészet a legmodernebb tengeralattjárókat mind háborús, mind békés időszakban sokféle célra fel tudja használni: „Elsődleges bevetési terület a Földközi-tenger, ahol Izrael jelenleg egyetlen tengeralattjáró-támaszpontja is van Haifában. Innen indulva a tengeralattjárók konfliktus vagy háború esetén többek között biztosítják a tengeri utánpótlásvonalakat, harcolnak az ellenséges tengeri erök ellen, zavarják az ellenség tengeri úton történő utánpótlását, támogatják a speciális erők szárazföldi akcióit (a tengeralattjáró rendelkezik zsilippel, hogy ilyen erőket partra tudjon tenni), részt vesznek tengeri területek és kikötők titkos aknásításában, valamint segítik tengeri vagy szárazföldi célok légitámadását" (Nassauer, 2011). Békeidőben a tengeralattjárók alapvető feladatai közé tartozik a terroristák tengeri szállítási tevékenységének megakadályozása. Emellett részt vesznek az elmúlt években Izrael partjainál felfedezett földgázmezők 
védelmében (В Киле, 2012). A nemzetközi vizeken tartózkodó, rejtőzködésre kiválóan alkalmas izraeli tengeralattjárók a zsidó állam biztonsága szempontjából rendkívül fontos felderítést, kémtevékenységet is folytatnak, adatokat és információkat szereznek, haditengerészeti tevékenységet, hadihajómozgásokat figyelnek meg.

\section{A tengeralattjáró-szállításokat övező politikai viták}

Németországban 2012 júniusában politikai diskurzus kereszttüzébe került az Izraelnek szállítandó Dolphin tengeralattjárók ügye. Az Angela Merkel ${ }^{13}$ (CDU) kancellár vezette szövetségi kormányon a harci fegyverek és egyéb katonai felszerelések exportjáról szóló 2000-es német alapelveket kérték számon, amelyek szerint harci fegyver nem szállítható olyan országokba, amelyek „külső fegyveres konfliktusban állnak, vagy amelyeknél fennáll a veszélye egy ilyen konfliktus kitörésének". A német kormányszóvivő, Steffen Seibert megerősítette, hogy Németország tartja magát ahhoz, hogy a náci korszak rémtettei miatti történelmi felelösség Izrael vonatkozásban felülírhatja a politikai elveket, s Angela Merkel szövetségi kancellár 2007-ben az ENSZ-ben tartott beszédére hivatkozott: „Minden korábbi szövetségi kancellár előttem kötelezve érezte magát arra, hogy Izrael létezéséért Németország különleges történelmi felelősségét biztosítsa. Én is kifejezetten elismerem ezt a különleges történelmi felelösséget. Ez országom államérdekének része." Merkel állásfoglalását, amely elvi szinten alátámasztotta a fegyverexport és a katonai együttmüködés területén a Németország és Izrael közötti különös kapcsolatot, azzal egészítette ki Seibert, hogy „a tengeralattjárók szállítása is ennek a felelősségnek a kifejezése". A német Védelmi Minisztérium egykori parlamenti államtitkára, Willy Wimmer (CDU) ugyancsak arra hívta fel a figyelmet, hogy a német szolidaritási kijelentések csak akkor hitelesek, ha mögöttük valóságos védelmi segítség mutatható ki. Ennek tényszerüségét az is mutatja, hogy a „német katonai együttmüködés Izraellel szorosabb, mint a legtöbb NATO-partnerrel" (Blechschmidt-Brössler, 2012).

Az Izraelnek szállítandó tengeralattjárók és más fegyverek Németországban Angela Merkel kancellársága idején már 2012 előtt is viták tárgyát képezték. Az erről szóló német politikai diskurzus homlokterében legtöbbször nem az a kérdés állt, hogy Izrael miként fejleszti tovább a német fegyvereket, felszereli-e tengeralattjáróit nukleáris töltetekkel - bár ez a kérdés is elökerült -, még csak nem is a költségmegállapodásokról vitáztak. A német politikai erők egy része elsősorban azt kifogásolta, hogy a Németország által katonai felszerelésekkel is támogatott Izrael politikai vezetése a német szövetségi kormány kérése ellenére sem akar változtatni a palesztinokat is érintő telepítési politikáján, nem mutat készséget arra, hogy a palesztinokkal komoly tárgyalásokat folytasson, illetve feltételekhez köti a palesztinoknak járó bevételek kifizetését a Palesztin Hatóságnak (Nassauer, 2011).

\section{Összegzés}

Izrael a hidegháború utáni évtizedekben leginkább Irántól érezte és érzi magát fenyegetve. A zsidó állam politikai vezetői kételkednek abban, hogy az iszlám köztársaság nukleáris ambícióit a nemzetközi közösség meg tudja fékezni, ezért a nukleáris elrettentő erő Izrael számára létfontosságú. A komplex izraeli védelmi politika egyik pillérét jelenti az a törekvés, hogy a zsidó állam a szárazföldi és légi védelem mellett nukleáris robbanótöltetek hordozására alkalmas robotrepülőgépekkel rendelkező modern tengeralattjárókkal csökkentse Izrael sebezhetőségét és hatékonyan ellensúlyozza az iráni nukleáris fegyverfejlesztéseket. A zsidó állam tengeralattjárói azért is kiemelt fontosságú komponensei az 
izraeli védelmi erőknek, mert Izrael ezekkel iráni atomtámadás esetén nemzetközi vizekről, a környező arab államok légterének megsértése nélkül képes nukleáris válaszcsapást mérni iráni célterületekre.

\section{Irodalomjegyzék}

Blechschmidt, Peter és Brössler, Daniel (2012): Historische Verantwortung sticht politische Grundsätze (5. Juni) Elérés: http://www.sueddeutsche.de/politik/ deutsche-u-boote-fuer-israel-historische-verantw ortung-sticht-politische-grundsaetze-1.1374358

Illés András (2005a): Az Izraeli Haditengerészet fejlődése és története (1967-1973) 1. rész. Belvedere, 3-4. sz. 67-87.

Illés András (2005b): Az Izraeli Haditengerészet fejlődése és története (1967-1973) 2. rész. Belvedere, 5-6. sz. 59-84.

Israel Submarine Capabilities (July 30, 2015). Elérés: http://www.nti.org/analysis/articles/israel-submarinecapabilities/

Izraeli csapásmérő tengeralattjárók Irán partjainál? (2008. április 20.) Elérés: http://www.haborumuveszete. hu/minden-ami-uszik/2299-izraeli-csapasmerotengeralattjarok-iran-partjainal

Lavy, George (1996): Germany and Israel: Moral Debt and National Interest. Frank Cass, London. DOI: 10.4324/9781315036335

Mahnaimi, Uzi és Campbell, Matthew (2000): Israel Makes Nuclear Waves With Submarine Missile Test.
London Sunday Times, June 18. Elérés: http://fas.org/ news/israel/e20000619israelmakes.htm

Mommsen, Klaus (2011): 60 Years Israel Navy. Bernard and Graefe, Bonn.

Nassauer, Otfried (2009): The German-Israeli Armaments Cooperation. (Mar 20.) Elérés: http:/ axisoflogic.com/artman/publish/Article_29923.shtml

Nassauer, Otfried (2011): Sechs Dolphin-U-Boote für Israels Abschreckung. BITS Research Note 11.1, Dezember. Elérés: http://www.bits.de/public/ researchnote/rn11-1.htm

Rogoway, Tyler (2016): Israel's Newest And Most Advanced Submarine Is Their Last Line Of Nuclear Deterrence (Jan 13.) Elérés: http://foxtrotalpha. jalopnik.com/israels-newest-and-most-advancedsubmarine-is-their-las-1752459324

Steinmetz, Christopher (2002): German-Israeli Armaments Cooperation. CAST: Eksport Vooruzheniy, No. 6, Nov/Dec. Elérés: http://www.bits.de/public/ articles/cast06-02.htm

В Киле спущен на воду четвертьй ,Дельфин” израильских ВМФ (21 февраля 2012 г.) Elérés: http:// newsru.co.il/world/21feb2012/dolphin307.html

\section{Jegyzetek}

${ }^{\text {Izrael }}$ Egyiptommal 1948-ban és 1956-ban is háborút viselt.

${ }^{2} \mathrm{~A}$ két tengeralattjáró nem vett részt második világháborús hadmüveletekben.

${ }^{3}$ A tragédia után egy évvel a gázai partoknál egy halász kifogta a Földközi-tenger keleti részén szerencsétlenül járt Dakar egyik mentőbójáját. Izrael három évtizeden át sikertelenül kerestette a tengeralattjáró maradványait. 1999 májusában a roncsok elökerültek, az azonban nem derült ki, hogy mi okozta a tengeralattjáró katasztrófáját.

${ }^{4}$ Helmut Kohl német kereszténydemokrata (CDU) politikus, 1982. október 1-től 1998. október 26-ig volt a Német Szövetségi Köztársaság kancellárja.

${ }^{5}$ A tengeralattjáró-vásárlási szerződést Németország és Izrael 1991 júliusában írta alá.

${ }^{6}$ Az öbölháború 1990. augusztus 2-án, Kuvait Irak általi lerohanásával kezdődött, és 1991. február 28-ig, az Irak által megszállt Kuvait felszabadításáig tartott.

${ }^{7}$ A három tengeralattjáró neve: Dolphin, Leviatan, Tekuma.
${ }^{8}$ Izrael hivatalosan nem nyilatkozott atomfegyver-programjáról, nem cáfolta, de nem is erősítette meg, hogy atomfegyverrel rendelkezik.

${ }^{9}$ Gerhard Schröder német szociáldemokrata (SPD) politikus, 1998. október 27-től 2005. november 21-ig volt Németország kancellárja.

${ }^{10}$ A tengeralattjáró-vásárlási szerződés aláírására Angela Merkel kancellársága idején, 2006 júliusában került sor. A német támogatást Izrael katonai területen igyekezett viszonozni: technológiai innovációkat adott a német légierőnek, kiképzésben részesített tengeralattjárókon szolgáló német katonákat.

${ }^{11}$ A negyedik új tengeralattjáró a Tannín, az ötödik a Ráháb nevet kapta.

${ }^{12}$ A tengeralattjáró-vásárlási szerződést Németország és Izrael 2012 márciusában írta alá.

${ }^{13}$ Angela Merkel német kereszténydemokrata (CDU) politikus, 2005. november 22-től Németország kancellárja. 